\title{
KONTRIBUSI PENGETAHUAN GIZI IBU DAN POLA ASUH GIZI TERHADAP STATUS GIZI ANAK BALITA DI JORONG SUNGAI SALAK KENAGARIAN KOTO TANGAH KECAMATAN TANJUNG EMAS KABUPATEN TANAH DATAR
}

\author{
Ifnala Rahayu ${ }^{1}$, Nizwardi Jalinus ${ }^{2}$, Yuliana $^{3}$ \\ 1,2,3 Universitas Negeri Padang, \\ e-mail: ifnalia.rahayu@gmail.com
}

\begin{abstract}
Abstrak
Berdasarkan observasi, permasalahan yang ada yaitu masih terdapat anak balita yang mengalami masalah gizi seperti : gizi kurang, gizi lebih, dan anak tumbuh pendek (stunting). Tujuan penelitian untuk mengungkap seberapa besar pengetahuan gizi ibu dan pola asuh gizi berkontribusi terhadap status gizi anak balita di Jorong Sungai Salak, Kenagarian Koto Tangah, Kecamatan Tanjung Emas, Kabupaten Tanah Datar. Metode yang digunakan adalah pendekatan kuantitatif. Sesuai dengan masalah dan tujuannya, penelitian ini bersifat ex-post facto. Subjek penelitian adalah anak balita yang berada di Jorong Sungai Salak, Kenagarian Koto Tangah, Kecamatan Tanjung Emas, Kabupaten Tanah Datar. Jenis data yang digunakan yaitu angket dan teknik pengumpulan data dengan menyebarkan kuesioner kepada orang tua anak balita. Analisis yang digunakan adalah analisis korelasi produk momen untuk melihat kontribusi antara variabel bebas dan variabel terikat. Selanjutnya menentukan kontribusi melalui pengolahan dengan analisis koefisien determinan. Hasil yang diperoleh dari penelitian ini sebagai berikut: (1) pengetahuan gizi ibu memberikan kontribusi sebesar $17,3 \%$ terhadap status gizi anak balita, (2) pola asuh gizi memberikan kontribusi sebesar $6 \%$ terhadap status gizi anak balita, (3) pengetahuan gizi ibu dan pola asuh gizi memberikan kontribusi sebesar 17,8 \% terhadap status gizi anak balita. Berdasarkan temuan penelitian ini disimpulkan bahwa pengetahuan gizi ibu dan pola asuh gizi berkontribusi terhadap status gizi anak balita.
\end{abstract}

Kata kunci : Pengetahuan Gizi Ibu, Pola Asuh Gizi, Status Gizi

\begin{abstract}
Based on observations, the problem is that there are still children under five who experience nutritional problems such as: lack of nutrition, over nutrition, and stunting. The purpose of the study was to reveal how much mother's nutritional knowledge and parental care contributed to the nutritional status of children under five in Jorong Sungai Salak, Kenagarian Koto Tangah, Tanjung Emas District, Tanah Datar District. The method used is a quantitative approach. In accordance with the problem and its purpose, this research is ex-post facto. Subjects were toddlers in Jorong Sungai Salak, Kenagarian Koto Tangah, Tanjung Emas District, Tanah Datar District. The type of data used is questionnaire and data collection techniques by distributing questionnaires to parents of children under five. The analysis used is the moment product correlation analysis to see the contribution between the independent variable and the dependent variable. Next determine the contribution through processing with determinant coefficient analysis. The results obtained from this study are as follows: (1) maternal nutrition knowledge contributes $17.3 \%$ to the nutritional status of children under five, (2) nutritional parenting contributes $6 \%$ to the nutritional status of children under five, (3) nutritional knowledge maternal and nutritional parenting contributed $17.8 \%$ to the nutritional status of children under five. Based on the findings of this study it was concluded that the mother's nutritional knowledge and parenting nutrition contribute to the nutritional status of children under five.
\end{abstract}

Keywords : Knowledge of Maternal Nutrition, Nutrition Parenting, Nutritional Status 


\section{PENDAHULUAN}

Sumber daya manusia menjadi salah satu faktor yang penting dalam meningkatkan status gizi yang baik untuk anak balita. Sesuai dengan tuntutan perubahan dunia serta teknologi yang semakin maju mendorong seseorang agar lebih unggul sehingga mampu bersaing dengan orang lain. Pembentukan sumber daya manusia harus dimulai sejak dini, yaitu sejak dalam kandungan dan semasa balita. Perkembangan dan pertumbuhan merupakan proses yang terjadi pada setiap makhluk ciptaan Tuhan. Pada manusia, proses tumbuh kembang terjadi sangat cepat terutama pada masa anak-anak, sedangkan tujuan utama pembangunan nasional adalah peningkatan kualitas SDM yang dilakukan secara berkelanjutan terutama pada status gizi anak balita.

Pembangunan kesehatan dalam periode tahun 2015-2019 difokuskan pada empat program prioritas yaitu penurunan angka kematian ibu dan bayi, penurunan prevalensi balita stunting (pendek), pengendalian penyakit menular dan pengendalian penyakit tidak menular. Upaya peningkatan status gizi masyarakat termasuk penurunan prevalensi balita pendek menjadi salah satu prioritas pembangunan nasional yang tercantum di dalam sasaran pokok Rencana Pembangunan Jangka Menengah (RPJM) Tahun 2015-2019. Target penurunan prevalensi stunting (pendek dan sangat pendek) pada anak baduta (dibawah 2 tahun) adalah menjadi 28\% (Kemenkes Rl; 2016).

Menurut Proverawati dan Wati (2011:62) "Secara harfiah anak balita adalah anak kurang dari lima tahun sehingga bayi usia dibawah satu tahun juga termasuk dalam golongan ini". Balita usia 1-5 tahun dapat digolongkan menjadi dua bagian usia, yaitu anak usia 1-3 tahun disebut dengan batita, dan anak usia 3-5 tahun yang dikenal dengan usia prasekolah dan lebih dikenal sebagai konsumen aktif. Anak dibawah 5 tahun merupakan kelompok yang menunjukkan pertumbuhan badan yang pesat, namun kelompok ini merupakan kelompok yang membutuhkan perhatian status gizi.

Pada saat ini, anak BALITA (Bawah Lima Tahun) sebagai generasi penerus bangsa yang diharapkan menjadi sumber daya manusia yang berkualitas di masa depan memerlukan perhatian khusus. Usia di bawah lima tahun merupakan "usia emas" dalam pembentukan sumber daya manusia baik dari segi pertumbuhan fisik maupun kecerdasan, dimana hal ini harus didukung oleh status gizi yang baik karena status gizi berperan dalam menentukan sukses tidaknya upaya peningkatan SDM terutama dalam pendidikan gizi di masyrakat.

Pendidikan gizi di masyarakat sangat diperlukan untuk dapat berperan serta memperbaiki pola hidup masyarakat dan membantu memperbaiki status gizi kesehatan khususnya melalui berbagai upaya preventif (pencegahan). Melalui tenaga kesehatan salah satu cara masyarakat dapat mengetahui berbagai informasi-informasi dan isu-isu kesehatan, khususnya yang berhubungan dengan gizi anak balita. Pendidikan gizi ini diberikan supaya masyarakat khususnya ibuibu yang memiliki anak balita tahu apa itu gizi, bagaimana memilih bahan makanan bergizi, manfaat gizi bagi kehidupan sehingga dapat memperbaiki status gizi anak balita.

Prevalensi status gizi anak balita berdasarkan indeks tinggi badan menurut umur (TB/U) di Provinsi Sumatera Barat $16,35 \%$ juga sangat pendek. Sedangkan untuk prevalensi status gizi berdasarkan indeks berat badan menurut tinggi badan (BB/TB) persentase di Indonesia yaitu $6,7 \%$ dan di Provinsi Sumatera Barat $4,1 \%$ sangat kurus (Firmana, dkk, 2015). Berdasarkan kelompok umur pada balita, semakin bertambah umur prevalensi stunting semakin meningkat. Prevalensi stunting paling tinggi pada usia 2435 bulan yaitu sebesar $42,0 \%$ dan menurun pada usia 36-47 bulan. Stunting lebih banyak terjadi pada anak laki-laki $(38,1 \%)$ dibandingkan dengan anak perempuan $(36,2 \%)$. Daerah perdesaan (42,1\%) mempunyai prevalensi stunting yang lebih tinggi dibandingkan daerah perkotaan (32,5\%). Menurut tingkat kepemilikan atau ekonomi penduduk, stunting lebih banyak terjadi pada mereka yang berada pada kuintil terbawah (Riskesdas, 2013).

Status gizi akan ditentukan oleh faktor eksternal dan internal. Faktor eksternal yang mempengaruhi antara lain ketersediaan bahan pangan pada suatu daerah, lingkungan tempat tinggal, pola asuh gizi dan pelayanan kesehatan yang tersedia di daerah tempat tinggal. Sedangkan faktor internal, antara lain cukup tidaknya pangan seseorang dan kemampuan tubuh menggunakan pangan tersebut. Cukup tidaknya pangan dapat dilihat dari pola makan yang dilakukan sehari-hari. Pola makan tersebut tergantung pada pengetahuan gizi yang dimiliki oleh penyelenggara makanan. Seperti yang dikemukakan Yetti, dkk (2015) bahwa kekurangan gizi disebabkan oleh kekurangan asupan makanan yang kurang, yang disebabkan oleh tidak tersedianya makanan 
yang adekuat, anak tidak cukup mendapat makanan bergizi seimbang, dan pola asuh gizi yang salah. Status gizi seseorang menunjukkan seberapa besar kebutuhan fisiologi individu tersebut telah terpenuhi. Keseimbangan antara nutrisi yang masuk dan nutrisi yang dibutuhkan untuk kesehatan optimal sangatlah penting, termasuk bagi seorang ibu yang sedang dalam masa menyusui. Masalah-masalah gizi tersebut sangat merisaukan karena mengancam kualitas sumber daya manusia dimasa mendatang.

Memiliki anak yang sehat dan cerdas adalah dambaan setiap orang tua. Untuk mewujudkannya tentu saja orang tua harus selalu memperhatikan, mengawasi dan merawat anak secara seksama. Khususnya memperhatikan pertumbuhan dan perkembangannya. Meskipun proses tumbuh kembang anak berlangsung secara alamiah, proses tersebut sangat bergantung kepada orang tua. Usia lima tahun (masa emas) adalah periode penting dalam tumbuh kembang anak dan merupakan masa yang akan menentukan pembentukan fisik, psikis dan intelegensinya (Sulistijani, 2001).

Seorang anak yang sehat dan normal akan tumbuh sesuai dengan potensi genetik yang dimilikinya. Tetapi pertumbuhan ini juga akan dipengaruhi oleh zat gizi yang dikonsumsi dalam bentuk makanan. Kekurangan atau kelebihan zat gizi akan dimanifestasikan dalam bentuk pertumbuhan yang menyimpang dari pola standar. Pertumbuhan fisik sering dijadikan indikator untuk mengukur status gizi baik individu maupun populasi. Oleh karena itu, orang tua perlu memberi perhatian pada aspek pertumbuhan anak apabila ingin mengetahui keadaan gizi mereka (Khomsan, 2003).

Kontribusi pengetahuan gizi seseorang ibu besar pengaruhnya bagi perubahan sikap dan perilaku di dalam pemilihan bahan makanan, yang selanjutnya akan berpengaruh pula pada status gizi individu dalam keluarga tersebut. Masalah gizi yang rendah disuatu daerah akan menentukan tingginya angka kurang gizi secara nasional (Mulyati, 1990).

Berdasarkan informasi yang penulis dapatkan dari posyandu di Jorong Sungai Salak Kenagarian Koto Tangah Kecamatan Tanjung Emas Kabupaten Tanah Datar dari hasil penimbangan berat badan dan pengukuran tinggi badan pada bulan Juni 2017 masih terdapat anak balita yang mengalami status gizi dari 84 anak balita terdapat 1,6\% anak balita mengalami gizi kurang, 1,2\% dari
84 orang anak balita mengalami gizi lebih dan $5,3 \%$ dari 84 orang anak balita mengalami tumbuh pendek.

Status gizi anak balita tidak lepas dari pola asuh gizi ibu dalam merawat anak balitanya. Pola asuh gizi merupakan praktek dirumah tangga yang diwujudkan dengan tersedianya pangan dan perawatan kesehatan serta sumber daya lainnya untuk kelansungan hidup, pertumbuhan dan perkembangan anak balita (Hellyta:2013). Pola asuh gizi merupakan faktor yang sangat erat kaitannya dengan pertumbuhan dan perkembangan anak berusia di bawah lima tahun. Masa anak usia 1-5 tahun (balita) adalah masa dimana anak masih sangat membutuhkan suplai makanan dan gizi dalam jumlah yang cukup dan memadai. Kekurangan gizi pada masa ini dapat menimbulkan gangguan tumbuh kembang secara fisik, mental, sosial dan intelektual yang sifatnya menetap dan terus dibawa sampai anak menjadi dewasa. Secara lebih spesifik, kekurangan gizi dapat menyebabkan keterlambatan pertumbuhan badan, lebih penting lagi keterlambatan perkembangan otak dan dapat pula terjadinya penurunan atau rendahnya daya tahan tubuh terhadap penyakit infeksi. Pada masa ini juga, anak masih benar-benar tergantung pada perawatan dan pengasuhan oleh ibunya. Pengasuhan kesehatan dan makanan pada tahun pertama kehidupan sangatlah penting untuk perkembangan anak (Santoso, 2005).

Praktek pola asuh gizi dalam rumah tangga biasanya berhubungan erat dengan faktor pendapatan keluarga, tingkat pendidikan dan pengetahuan gizi ibu. Menurut Suhardjo (1986:33) anak-anak yang tumbuh dalam suatu keluarga miskin adalah paling rawan terhadap kurang gizi diantara seluruh anggota keluarga lainnya dan anak yang kecil biasanya paling terpengaruh oleh kurang pangan. Sebab dengan bertambahnya jumlah anggota keluarga maka pangan untuk setiap anak berkurang dan banyak orang tua yang tidak menyadari bahwa anak-anak yang sangat muda perlu zat gizi yang relatif lebih banyak dari pada anak-anak yang lebih tua. Dengan demikian anak-anak yang lebih muda mungkin tidak diberi cukup makanan yang memenuhi kebutuhan gizi. Keadaan diatas akan lebih buruk jika ibu anak balita memiliki perilaku pola asuh yang kurang baik dalam hal penyusuan, pemberian MP-ASI serta pembagian makanan dalam keluarga. Di dalam keluarga besar dengan keadaan ekonomi lemah, anak-anak dapat menderita oleh karena peghasilan keluarga harus digunakan oleh banyak orang. Semakin banyak jumlah anggota keluarga, 
tentunya akan semakin bervariasi aktivitas, pekerjaan dan seleranya. Sehingga jumlah anggota keluarga berkaitan dengan pemenuhan kebutuhan gizi yang dipengaruhi oleh konsumsi makanan. Dalam hal ini faktor selera dari masing-masing anggota keluarga sangat berpengaruh. Tidak semua anggota keluarga menyukai jenis makanan yang sama. Kecil kemungkinan seorang ibu rumah tangga menyediakan jenis makanan yang berbedabeda setiap hari sesuai keinginan tiap anaknya, ditambah juga diperlukan makanan khusus untuk anak balita sebagai MP-ASI.

Dalam kehidupan sehari-hari dari 84 orang ibu anak balita, 10 orang yang penulis amati pada bulan Juni 2017 terlihat keluarga yang sungguhpun berpenghasilan cukup akan tetapi makanan yang disajikan seadanya saja. Ibu anak balita hanya menyajikan : karbohidrat dan protein saja, karbohidrat dan sayur, atau nasi dengan garam dan minyak, anak balita sering diberikan mie instant, anak jarang sekali diberikan buah-buahan. Terlihat dari kehidupan sehari-hari anak balita yang belum cukup 6 bulan sudah diberikan makanan pendamping ASI oleh ibunya, bahkan masih ada ibu yang memberikan makanan/minuman prelaktal kepada bayi yang baru lahir dengan alasan ASInya belum keluar. Jenis makanan/minuman prelaktal yang sering diberikan oleh ibu anak balita adalah, madu, air tajin, pisang, dan susu formula. lbu anak balita dalam menyiapkan makanan untuk anaknya tidak terlihat mereka memperhatikan hygiene dan sanitasinya, terlihat dari peralatan, dan bahan makanan tidak dicuci terlalu bersih sebelum mengolah dan menyajikan makanan untuk anak balita. Dengan demikian, kejadian gangguan gizi tidak hanya ditemukan pada keluarga yang berpenghasilan kurang akan tetapi juga pada keluarga yang berpenghasilan relatif baik (cukup). Keadaan ini menunjukkan bahwa ketidak tahuan akan kaidah pola asuh gizi anak balita.

Berdasarkan informasi yang penulis dapatkan dari kader posyandu yaitu masalah status gizi anak balita di Jorong Sungai Salak Kenagarian Koto Tangah Kecamatan Tanjung Emas Kabupaten Tanah Datar terhadap hasil penimbangan berat badan dan pengukuran tinggi badan, masih terdapat anak balita yang mengalami masalah gizi seperti : gizi kurang, gizi lebih, dan anak tumbuh pendek (stunting). Berdasarkan ungkapan tersebut maka peneliti tertarik untuk melakukan penelitian dan menggali lebih jauh tentang Kontribusi Pengetahuan Gizi Ibu Dan Pola Asuh Gizi Terhadap Status Gizi Anak Balita Di
Jorong Sungai Salak, Kenagarian Koto Tangah, Kecamatan Tanjung Emas, Kabupaten Tanah Datar.

\section{METODE}

Penelitian ini menggunakan pendekatan kuantitatif. Sesuai dengan masalah dan tujuannya, penelitian ini bersifat ex-post facto, yaitu mengungkap data dari peristiwa-peristiwa yang telah lalu dan kemudian menuntut ke belakang untuk menemukan faktor-faktor yang mendahului atau menentukan sebab-sebab yang mungkin atas peristiwa yang diteliti (Sugiyono: 2009).

Menurut Wiersma (1986:172) "Expost facto research is systematic and empirical inquiry in which the independent variabel have already accurred and are inherely not manipulable by the researcher". Dalam penelitian ini variabel-variabel yang diteliti tidak dikendalikan atau dimanipulasi, tetapi dari fakta diungkap apa adanya kontribusi pengetahuan gizi ibu dan pola asuh gizi terhadap status gizi anak balita di Jorong Sungai Salak Kenagarian Koto Tangah Kecamatan Tanjung Emas Kabupaten Tanah Datar.

\section{HASIL DAN PEMBAHASAN}

Penelitian ini telah menunjukkan gambaran tentang Kontribusi Pengetahuan Gizi Ibu dan Pola Asuh Gizi Terhadap Status Gizi Anak Balita di Jorong Sungai Salak Kenagarian Koto Tangah Kecamatan Tanjung Emas Kabupaten Tanah Datar. Rangkuman analisis korelasi sederhana dan ganda dapat dilihat dibawah ini.

\section{Hipotesis Pertama Pengetahuan Gizi ibu terhadap Status Gizi BB/TB}

Berdasarkan rangkaian analisis data penelitian, ditemukan bahwa terdapat kontribusi antara Pengetahuan gizi ibu $\left(X_{1}\right)$ terhadap status gizi anak balita $(Y)$ dengan koofisien korelasi 0,416 dan koefisien determinasinya 0,173 yang mempunyai arti pengetahuan gizi ibu memberikan kontribusi sebesar $17,3 \%$ terhadap status gizi setelah melakukan uji signifikan pada taraf 5\%. Dengan demikian pengetahuan gizi ibu memberikan kontribusi terhadap status gizi.

Menurut

Sajogyo

(1978:41)

"Pengetahuan gizi adalah kepandaian memilih makanan yang bergizi dan kepandaian dalam mengolah bahan makanan yang diberikan kepada anak balita". Pengetahuan tentang ilmu gizi secara umum sangat bermanfaat dalam sikap dan perlakuan dalam memilih bahan makanan. Pengetahuan gizi merupakan 
pengetahuan tentang makanan dan zat gizi, sumber-sumber zat gizi pada makanan, makanan yang aman dikonsumsi sehingga tidak menimbulkan penyakit dan cara mengolah makanan yang baik agar zat gizi dalam makanan tidak hilang serta bagaimana hidup sehat (Notoatmojo, 2003:98).

Pengetahuan gizi dipengaruhi oleh beberapa faktor, disamping pendidikan yang pernah dijalani, faktor lingkungan sosial dan frekuensi kontak dengan media massa juga mempengaruhi pengetahuan gizi. Pengetahuan gizi memegang peranan yang sangat penting didalam penggunaan dan pemilihan bahan makanan dengan baik, sehingga dapat mencapai keadaan gizi seimbang (Suhardjo, 1989:67:71).

Menurut teori di atas, menyatakan bahwa terdapat kontribusi antara Pengetahuan gizi ibu terhadap status gizi anak balita BB/TB.

\section{Hipotesis Kedua Pola Asuh Gizi terhadap Status Gizi}

Berdasarkan rangkaian analisis data penelitian, ditemukan bahwa terdapat kontribusi antara pola asuh gizi $\left(X_{2}\right)$ terhadap status gizi $(Y)$ dengan koofisien korelasi 0,246 dan koefisien determinasinya 0,060 yang mempunyai arti pola asuh gizi memberikan kontribusi sebesar $6 \%$ terhadap status gizi anak balita berdasarkan setelah melakukan uji signifikan pada taraf $5 \%$. Dengan demikian pola asuh gizi memberikan kontribusi terhadap status gizi anak balita.

Pola asuh anak berupa sikap perilaku ibu atau pengasuh lain dalam hal kedekatan dengan anak, memberikan makan, perawatan, menjaga kebersihan, memberikan kasih sayang dan sebagainya. Hal ini berhubungan dengan keadaan ibu tentang kesehatan (fisik dan mental), status gizi, pendidikan, penghasilan, pengetahuan, dan ketrampilan tentang pengasuhan anak yang baik, peran dalam keluarga, atau masyarakat, dan sebagainya dari ibu atau pengasuh anak (Sunarti, 2000).

Menurut (Soekirman,2000) pola asuh gizi merupakan perubahan sikap dan perilaku ibu atau pengasuh lain dalam hal memberi makan, kebersihan, memberi kasih sayangdan sebagainya dan semuanya berhubungandengan keadaan ibu dalam hal kesehatan fisikdan mental. Pola asuh yang baik dari ibu akan memberikan kontribusi yang besar pada pertumbunhan dan perkembangan balita sehingga akan menurunkan angka kejadian gangguan gizi. Ibu harus memahami cara memberikan perawatan dan perlindungan terhadap anaknya agar anak menjadi nyaman, meningkat nafsu makannya, terhindar dari cedera dan penyakit yang akan menghambat.

Pola asuh gizi merupakan bagian dari pola asuh anak yaitu praktik dirumah tangga yang diwujudkan dengan tersedianya pangan dan perawatan kesehatan serta sumberlainnya untuk kelansungan hidup, pertumbuhan dan perkembangan anak. Aspek kunci dalam pola asuh gizi meliputi perawatan dan perlindungan bagi ibu, praktik menyusui, pemberian Makanan Pendamping Air Susu Ibu (MP-ASI), penyiapan makanan, kebersihan diri dan sanitasi lingkungan, praktik kesehatan di rumah dan pola pencarian pelayanan kesehatan (Zeitlin dalam Nura:2010).

Dari pendapat di atas dapat disimpulkan bahwa terdapat kontribusi antara pola asuh gizi $\left(\mathrm{X}_{2}\right)$ terhadap status gizi $(\mathrm{Y})$.

\section{Hipotesis Ketiga Pengetahuan Gizi Ibu dan Pola Asuh Gizi terhadap Status Gizi}

Berdasarkan rangkaian analisis data penelitian, ditemukan bahwa terdapat kontribusi antara pengetahuan gizi ibu $\left(X_{1}\right)$ dan pola asuh gizi $\left(X_{2}\right)$ terhadap status gizi anak balita $(Y)$ dengan koofisien korelasi 0,421 dan koefisien determinasinya 0,178 yang mempunyai arti pengetahuan gizi ibu dan pola asuh gizi memberikan kontribusi sebesar 17,8 $\%$ terhadap status gizi anak balita setelah melakukan uji signifikan pada taraf 5\%. Dengan demikian pengetahuan gizi ibu dan pola asuh gizi membeikan kontribusi terhadap status gizi anak balita.

Tingkat pengetahuan gizi ibu sebagai pengelola rumah tangga akan berpengaruh pada jenis bahan makanan yang dikonsumsinya oleh anak balitanya. Pengetahuan gizi ibu adalah peguasaan seseorang ibu terhadap kebutuhan zat gizi yang cukup untuk merubah perilaku yang kurang benar sehingga dapat memilih bahan makanan bergizi serta menyusun menu 3B sesuai dengan kebutuhan anak balita (Depkes RI, 2002). Menurut Djaeni (1991:24) "Pengetahuan gizi ibu juga merupakan faktor kunci dalam pola asuh gizi dalam rumah tangga, karena ibu sangat berhubungan erat dengan pola asuh dan tumbuh kembangnya anak".

Menurut (Soekirman,2000) pola asuh gizi merupakan perubahan sikap dan perilaku ibu atau pengasuh lain dalam hal memberi makan, kebersihan, memberi kasih sayangdan sebagainya dan semuanya berhubungandengan keadaan ibu dalam hal kesehatan fisikdan mental. Pola asuh yang baik dari ibu akan memberikan kontribusi yang besar pada pertumbunhan dan perkembangan 
balita sehingga akan menurunkan angka kejadian gangguan gizi. Ibu harus memahami cara memberikan perawatan dan perlindungan terhadap anaknya agar anak menjadi nyaman, meningkat nafsu makannya, terhindar dari cedera dan penyakit yang akan menghambat.

Dari pendapat di atas dapat disimpulkan bahwa terdapat kontribusi antara pengetahuan gizi ibu $\left(X_{1}\right)$ dan pola asuh gizi $\left(\mathrm{X}_{2}\right)$ terhadap status gizi anak balita $(\mathrm{Y})$

\section{PENUTUP}

Berdasarkan hail analisis penelitian ini, dapat diambil kesimpulan sebagai berikut: 1) Terdapat kontribusi antara pengetahuan gizi ibu $\left(X_{1}\right)$ terhadap status gizi anak balita $(Y)$ dengan koofisien korelasi 0,416 dan koefisien determinasinya 0,173 yang mempunyai arti pengetahuan gizi ibu memberikan kontribusi sebesar $17,3 \%$ terhadap status gizi anak balita setelah melakukan uji signifikan pada taraf $5 \%$. Dengan demikian pengetahuan gizi ibu membeikan kontribusi terhadap status gizi anak balita. 2) Terdapat kontribusi antara pola asuh gizi $\left(X_{2}\right)$ terhadap status gizi anak balita (Y) dengan koofisien korelasi 0,246 dan koefisien determinasinya 0,060 yang mempunyai arti pola asuh gizi memberikan kontribusi sebesar $6 \%$ terhadap status gizi anak balita setelah melakukan uji signifikan pada taraf $5 \%$. Dengan demikian pola asuh gizi membeikan kontribusi terhadap status gizi anak balita. 3) Terdapat kontribusi antara pengetahuan gizi ibu $\left(\mathrm{X}_{1}\right)$ dan pola asuh gizi $\left(\mathrm{X}_{2}\right)$ terhadap status gizi anak balita $(\mathrm{Y})$ dengan koofisien korelasi 0,421 dan koefisien determinasinya 0,178 yang mempunyai arti pengetahuan gizi ibu dan pola asuh gizi memberikan kontribusi sebesar 17,8\% terhadap status gizi anak balita setelah melakukan uji signifikan pada taraf $5 \%$. Dengan demikian pengetahuan gizi ibu dan pola asuh gizi membeikan kontribusi terhadap status gizi anak balita.

Berdasarkan kesimpulan diatas dapat diajukan saran sebagai berikut: 1) Bagi instansi kesehatan untuk meningkatkan upaya sosialisasi status gizi dikalangan masyarakat, khususnya ibu yang memiliki balita melalui penyuluhan secara berkala dan melalui penyebaran brosur yang berisi tentang status gizi serta cara pemilihan, penyimpanan, pengolahan dan penyajian makanan yang baik untuk balita. 2) Bagi masyarakat dan ibu anak balita supaya mencari informasi sebanyakbanyaknya tentang cara pemilihan, penyimpanan, pengolahan dan penyajian makanan bagi balita, yang memenuhi syarat menu 3B yang ditetapkan pemerintah, yaitu makanan yang beragam secara jenis, bergizi dari kandungan makanan tersebut, serta berimbang kadar gizi yang terkandung dalam makanan tersebut. 3) Bagi penelitian selanjutnya diharapkan untuk meneliti tentang faktor lain yang mempengaruhi status gizi balita.

\section{DAFTAR PUSTAKA}

Atikah Proverawati, dan Erna, Kusuma, W, (2011). IImu Gizi Untuk Keperawatan Dan Gizi Kesehatan. Yogyakarta : Nuha Medika.

Depkes RI, (2002). Pedoman Umum Gizi Seimbang. Jakarta : Depkes.

Djaeni, Ahmad, (1976). IImu Gizi dan IImu Diit di Daerah Tropik. Jakarta : Balai Pustaka.

Firmana, Putri, R dkk, (2015). Faktor-Faktor yang Berhubungan dengan Status Gizi Anak Balita di Wilayah Kerja Puskesmas Nanggalo Padang. (Jurnal). Di akses Januari 2017 dari (http://jurnal.fk.unand.ac.id).

Hellyta, Haska, (2013). Pengetahuan Gizi Ibu, Pola Asuh Dan Status Gizi Bayi Di Desa Bojong Jengkol, Kecamatan Ciampea, Kabupaten Bogor. (Skripsi). Bogor. Departemen Gizi Masyarakat Fakultas Ekologi Manusia Institut Pertanian Bogor.

Kemenkes, (2016). Pemantauan Status Gizi Di Seluruh Kabupaten/Kota Di Indonesia. Jakarta.

Khomsan. A, (2003). Pangan Dan Gizi Untuk Kesehatan. PT. Grafindo Persada, Jakarta.

Notoatmodjo, Soekidjo, (2003). Pendidikan Dan Perilaku kesehatan. Jakarta : Rineka Cipta.

Nura, Veriyal, (2010). Analisis Pola Asuh Gizi Ibu Terhadap Balita Kurang Energi Protein Yang Mendapat PMT-P Di Puskesmas Pegedangan Kabupaten Tanggerang. (Skripsi). Jakarta. Universitas Islam Negeri Syarif Hidayatullah. 
Riskesdas, 2013. Penyajian Pokok-pokok Hasil Riset Kesehatan Dasar 2013. Badan Penelitian dan Pengembangan Kesehatan, Kementerian Kesehatan RI. Akses www.litbang.depkes.go.id.

Sajogyo, (1994). Menuju gizi baik yang merata di pedesaandan di kota. Gajah Mada Univeresity Press: Yogyakarta.

Santoso, Soegeng dan Lies, Anne, (2013). Kesehatan dan Gizi. Jakarta : Rineka Cipta.

Soekirman, (2000). IImu Gizi dan Aplikasinya untuk Keluarga dan Masyarakat. Direktorat Jendral Pendidikan Tinggi Departemen Pendidikan Nasional, Jakarta.

Suhardjo, dkk, (1986). Pangan, Gizi dan Pertanian. Jakarta : UI-Press.

Sulistijani. A.D, (2001). Menjaga Kesehatan Bayi dan Balita. Jakarta : Puspa Swara

Sunarti, dkk, (2000). Pola Pengasuhan Anak secara Tradisional di Kelurahan Kebagusan Daerah lbu Kota Jakarta. Depdikbud

Sri, Mulyati.(1990). Penelitian Gizi dan Makanan. Bogor : Puslitbang Bogor.

Wiersma, William, (1986). Research Method in Education: an iducation. Massachusetts: Allyn an Bacon, Inc.

Yetty, Nency dkk. Gizi Buruk, Ancaman Generasi yang Hilang. Di akses Desember 2016 dari (http://io.ppijepang.org/article.php?id=113). 